\title{
Character and Discourse from Pirandello to Fellini: Defining a Countertradition in an Italian Context
}

In his book Rabelais and His World, Mikhail Bakhtin points to the revolutionary nature of medieval camival. According to the famous Russian intellectual, carnival is a revolution where kings are decapitated and crowds are crowned. However, more than simply formulating an ideological reading of carnival as actual liberation, I believe that, with the sum of his writings, Bakhtin provides us with a model of interpretation for a mode of discourse-in society and in literature-meant to subvert the monologism of authoritarian discourse. Thus Bakhtin's renowned study of Dostoevsky's poetics (Problems), for instance, can be extremely inspirational in our reading and interpretation of that counter-tradition in narrative as well as dramatic art which, I believe, started in Italy with Pirandello and then developed in contrast to, or rather in critical dialogue with, more traditionally accepted modes of discourse such as tragedy and comedy.

The close relationship between carnival and comedy is accurately discussed by Umberto Eco in his article "The Frames of Comic 'Freedom'." Here he states that "comedy and carnival are not instances of real transgression; on the contrary, they represent paramount examples of law reinforcement. They remind us of the existence of the rule" (6). Since the Romantic period, however, many scholars and artists have dealt with and spoken about a mode of discourse which differs from comedy, one variously defined as irony or humor. According to Eco, such discourse varies from comedy primarily because of the differently balanced relationship between rule and violation (7). In his essay on humor, "L'umorismo", Luigi Pirandello defines the comic as the perception of the opposite, while humor is the feeling of the opposite produced by the "special" activity of reflection. Pirandello supports his argument by giving the example of an old woman who smears her face with make up and wears flashy clothes. In comedy, one would simply understand that she is not what a respectable old lady ought to be (and "we" are), and would laugh at her. In humor, one would "see" why the woman masks herself: that is, that she strives to regain at least the appearance of her lost youth in order not to lose her much younger husband. Thus in humor one finds oneself halfway between tragedy and comedy. The laughter of comedy merges with 
the pity of tragedy and becomes a smile. We still feel a sense of superiority, but it soon becomes mixed with a shade of tenderness.

As Eco remarks, in comedy we laugh at the character who breaks the rule, the set of social values, or in other words, the frame. In tragedy we sympathize with the character who has broken the frame but we enjoy the reaffirmation of the rule. In humor, instead, we smile because of the contradiction between the character and the frame the character cannot comply with. But we are no longer so certain that the character is at fault. It may be that the frame is wrong. By restoring the binary opposition between the character and the rule in a dialectic and open-ended fashion, humor acts as a form of social criticism and so is truly transgressive while comedy is not. Moreover, since humor, as Eco maintains, "works in the interstices between narrative and discursive structures" (8), it necessarily re-defines the roles of the various elements involved in the textual production-the author, the audience or the reader, the text itself, and, obviously, the character. Humor, then, is always metalinguistic and/or metasemiotic.

Bearing in mind such theoretical premises, an apparently hazardous operation such as that of instituting a paraliel between Luigi Pirandello and Federico Fellini may prove useful and revealing if carried out against the background of the serio-comical genre. Within this theoretical and cultural frame, to verify similarities and affinities between Pirandello and Fellini, and in particular between the two authors' conception of character as well as their privileged forms of discourse will prove a challenging, but ultimately revealing journey. A case of direct influence can hardly be proven, for on the one hand we do not possess examples of direct adaptations, and on the other Fellini would very unlikely admit such an influence. It is necessary, then, to assume a broader perspective rather than that provided by a positivistic juxtaposition of a literary and a cinematic text. As a matter of fact, I believe that a relationship between Pirandello's and Fellini's works can be legitimately and fruitfully discussed only against the background of the cultural countertradition of the serio-comical, as it has been variously defined by Mikhail Bakhtin and Luigi Pirandello himself. This particular genre finds its privileged linguistic expression in meta-discourse, a discourse that is, by its very nature, self-reflexive and self-referential as well as extremely ambivalent. On a linguistic level, meta-discourses both postulate the destruction of traditional narrative and dramatic strategies, and encourage the search for the "new" in art. In their dismantlement of traditionally accepted artistic conventions and social hierarchies, these discourses participate in what Mikhail Bakhtin has defined as the "carnival sense of the world" (Problems 122-37), ${ }^{1}$ that is, a forceful drive towards transgression, or rather subversion, of the rule, of the Law, and, last but not least, of the frame.

According to Pirandello, to unmask the lie, and thus to denounce the fictionality of the frame or at least to challenge its constrictive boundaries both in a social and in a literary text becomes imperative for the "umorista." 
In order to pursue such a thorough investigation of the social and literary text, the typical Pirandellian "umorista" forces himself to undergo a progressive dissemination, or in other words thoroughly exploits the infinite possibilities provided by being author, character, and spectator or reader simultaneously. This multiplicity of roles, or rather, this constant role playing and exchanging between the various participants in the textual production constitutes, perhaps, one of the most inspirational tenets of Pirandello's legacy to Federico Fellini, for the Italian director's work follows a quite similar process.

At the very foundation of both the author's and the character's dissemination in multiple roles stands Pirandello's concept of humor. The Italian artist and intellectual defines humor also as "a phenomenon of doubling in the act of artistic conception" (120). The reflection which produces the feeling of the opposite is a kind of projection of the very activity of the creative imagination: such a reflection originates from the mental image like a shadow from a body. As a consequence of this process of internal doubling which takes place deep inside the creative mind, the hero no longer has a given, fixed image, but is constantly doubled, and hence better defined as an "anti-hero." As a result, Pirandello's typical Subject as "umorista" is constitutionally ambivalent, eccentric, and yet fully self-conscious. Such a Subject is thus defined by the sum of his consciousness and self-consciousness, by his conscious and subconscious life. Within the framework of a genre without qualifying adjectives, or rather "umoristico"- a gerre which pursues the break with monologic discourse that started with the Socratic dialogue via the non-hierarchic dissemination of truth in multiple voices,--the hero becomes not simply the object of the author's discourse, but also the subject of his own discourse. This is the condition of Pirandello's characters in search of an author, and, I believe, of Fellini's obsessive images, his "phantoms" as he himself calls them. ${ }^{2}$

In an essay entitled "Pirandello e l'oltre," included in the volume Dalle parti di Pirandello, Paolo Puppa makes an interesting parallel between the condition of the lawyer and that of the author, and maintains that in the Pirandellian plot, continuous exchanges take place between the two. ${ }^{3}$ What allows the movement from one role to the other is the concept of "soul" which, according to Puppa, gives birth to the idea of character.

Ebbene, a permettere la trasparenza tra avvocato e auctor, a consentire alchemici trapassi da un ruolo all'altro, è proprio il concetto d'anima, da cui germina in una confusione terminologica tra l'estetico e l'estatico, l'idea di personaggio. (55)

Puppa further maintains that the relationship between lawyer and clients, between judge and accused recalls inexorably the fantastic meeting between author and characters. ${ }^{4}$ One needs to trespass the societal and ritual thresholds, and thus, what needs to be found is a door to the "oltre," to the "al di là," that is, the "beyond" as Pirandello terms it, ${ }^{5}$ or to the "subconscious," to define 
it in Fellini's terms. ${ }^{6}$ It is there, in that mysterious place that their phantoms await to be given life.

As a matter of fact, innumerable references to the spirits, that is, to both the voices from "beyond" and those from "within" which undermine the very ontology of the Subject, appear in Fellini's entire cinema, ${ }^{7}$ but particularly in his masterpiece $81 / 2$ (1963) where they are immediately linked to the problem of artistic creation and existential plenitude. ${ }^{8}$ This film is the cinematic narration of a director's total existential and artistic crisis: it is the story of an individual who, once confronted by the many different voices which pressure him from inside and outside himself, progressively loses contact with all of them and experiences a state of complete confusion. For instance, during a visit with some friends and a few production people to the space-ship built for the science-fiction film he is supposed to shoot (but never will), Guido Anselmi, the protagonist, first admits he has nothing to say but wants to say it anyway. He then turns to Rossella, his wife's best friend, and anxiously asks her what her "spirits" think about him. She answers: "They always say the same things, even right now. They're very reasonable spirits. They know you very well .... They say that you're free. But you have to choose, and you haven't got much time left" (Affron 132).

In his quest for recognition of both his social and artistic identity, Guido constantly cries out for help. First of all, he seeks assistance from the multiplicity of socially constituted voices that surround him: the voices of his mother, father, wife, lover, critic, producer, and, last but not least, the overwhelming voice of the Church. Secondly, he asks for help from the "spirits," the voices from within and from beyond. In both instances, however, the Subject must choose; in fact, "to choose" seems to equal "to be," in social as well as in existential terms. The quest for recognition and the recognition of loss become the central guidelines of Fellini's masterpiece. The loss that is recognized is a loss of identity on behalf of the author/Fellini, of the characters, and of the text itself. What Pirandello expressed in his famous theatrical trilogy as the circular search for something lacking, ${ }^{9}$ Fellini's $81 / 2$ expresses in terms of a loss, the loss of the Other and/or the others produced by the act of choosing. Having lost his identity, the Subject tries to recover it in relationship both to the Other (inside the Self) and to others (outside the Self). ${ }^{10}$

In both Pirandello's and Fellini's works, spirits, phantoms, and obsessive shadows pressure the author from beyond and from within. Legal procedures often trespass onto the realm of spiritualist séances, of magic rituals. When this occurs, the author is obviously forced into the ambivalent role of the "medium." However, an author actually is a medium, a translator of an image born in his imagination into words and/or cinematic images. According to Pirandello, a further and often fatal mediation takes place in theatre through the representation of the character by the actor. What is ultimately left of 
the creature, the living image that initially pressured the author into receiving new life, becomes simply "un adattamento, una maschera, anziché una vera incarnazione," (1908; "Illustratori," 215; "an adaptation, a mask, and not a true embodiment") when it achieves concrete form on the stage. ${ }^{12}$

The problematic relationship between director and actors is likewise analyzed in Federico Fellini's $81 / 2$ when, close to the end of the movie, the protagonist's artistic crisis reaches its peak during the viewing of the screentests for the film to be made. The overwhelming distance between the original images and voices as they presented themselves in the director's imagination and the banal, mundane form of the provini (the screen-tests are already parts of a symbolic apparatus) cannot be bridged by the feeble efforts of the actors, mere shadows on a screen within the screen. Fellini analyzes and thematizes the intriguing question of the true nature of the character, as well as that of the author, in many of his narrative films, but particularly in $81 / 2$, a work which constitutes a cinematic parallel to Pirandello's trilogy of the "theatre in the theatre." 13

The fundamental problem these two authors face seems to lie, ultimately, in the "independence" of their characters. Essentially because of this peculiar condition of their characters, both artists ultimately lack the possibility of creating an authentic autobiography. In both Pirandello's and Fellini's artistic visions, this condition of independence of the character becomes clear in numerous instances. Their characters are like obsessive phantoms appearing from some other life and pressuring the author into giving them true artistic expression and thus new life. However, no single form can actually fulfill these shadows' thirst for life; therefore they remain in the darkness of the artist's imagination, returning obsessively over and over again. This may explain the apparent monotony which characterizes Pirandello's and Fellini's conspicuous galleries of characters. It needs to be remembered, though, that this is a monotony in diversity, for in a text defined as "umoristico" no single-faced character and no-single toned truth exist.

In Pirandello's entire artistic work, characters come and go-from short story to novel, from novel to essay, from everywhere to the screeching stage of his theatre. Sometimes they arrive totally unchanged, sometimes they are slightly modified, although more in their physical than in their psychological substance. The same occurs in Fellini's cinema, where similar characters appear over and over. Moraldo jumps from I vitelloni (1953) to La dolce vita (1959) and becomes Marcello; from La Dolce Vita, Marcello then jumps to $81 / 2$ and there becomes Guido, the character-director, who eventually becomes Fellini himself in the trilogy of the cinema in the cinema: Fellini: A Director's Notebook, I clowns (1970), and Roma (1972). Ultimately, all these characters, together with their various sympathetic companions, jump into Amarcord (1974), a film which develops through a choir of perspectives rather than through the experience of a single consciousness (that of Fellini) which attempts to re-visit its own past. 
In the case of both Luigi Pirandello and Federico Fellini, first-person narration rarely assumes the form of a comforting "monologue intérieur" typical of the Proustian form of recollecting past autobiographical memories. The return of the past in Pirandello and in Fellini is characterized by a loss of the "aura" which permeates the "memoria involontaria" of Proust's A la recherche du temps perdu (1913-27). What emerges from an image long before experienced by the Subject is a stratified construction strewn with non-homogeneous series of images, "Remembering is a little like dreaming: it produces hiatuses between narrative sequences that elide each other." ("Ricordare è un po' sognare, produce iati fra le sequenze che si elidono a vicenda," Puppa 153). Nevertheless, for Pirandello's anti-heroes the act of writing becomes central, since through the written word they try desperately to narrate their painful distance from the world. A quite similar process takes place in many of Fellini's films, where the presence of the director as character within the story does not simply serve as a narrative device. Instead, together with the very act of film-making, it seems to compensate the Subject partially for his loss of contact with reality, as is clearly the case in such films as $81 / 2$ and Fellini's Roma.

As we have tried to outline here, the complex question revolving around the nature of the character as "umorista" is central to most of Pirandello's works. However, it is certainly most crucial to his "novels of identity," Il fu Mattia Pascal (1904), Si gira . . . (1915-16), and Uno, nessuno e centomila (1926). In these narrative works, the main character bears strong similarities to the central figure in Dostoevsky's "The Dream of a Ridiculous Man." In this character, as Bakhtin points out, "there are clear traces of the ambivalent-serio-comical-image of the wise-fool and tragic clown of carnivalized literature" (Problems 150). One of Fellini's most important artistic statements on character is certainly his film The Clowns, and it is not by chance that in order to provide a full definition of his conception of character the director turns to the world of the circus. His attention focuses on the ambivalent figure of the clown in its two variants, the "Augusto" and the White Clown, contradictory embodiments of opposites. ${ }^{14}$ The Pirandellian concept of humor-that is, that "feeling of the opposite"-thus seems to constitute the most obvious source of Fellini's conception of character. Fellini once declared, while speaking about the making of La Strada:

Gelsomina appeared to me in the guise of a clown, and immediately beside her, as a contrast, there appeared a massive and dark shadow, Zampand. And, naturally, the road, the circus with its colorful rags, its menacing and heartbreaking music, its cruel fairy-tale atmosphere. (182-83)

It may be useful to note, here, that Fellini frequently places his ambivalent and eccentric characters in the equally ambivalent and eccentric atmosphere of the circus, a social institution that reflects the carnival atmosphere better than any art form can. 
As Elio Gioanola observes in his book Pirandello la follia (20-21), only with Dostoevsky does the protagonist of the novel first become an anti-hero, or in other words a madman without qualities, a ridiculous man. After the bourgeois revolution, the traditional Hegelian master-slave dialectic gets replaced with the Freudian opposition father-son which generates all modern forms of nervous suffering. ${ }^{15}$ While before, it was certainly impossible to kill God and men could only laugh at Him by making a parody of (parodying) His sacredness, now that the father has taken His place, it has become possible to kill God-that is, the Father. This fatal temptation leaves the Son full of remorse and pain, and possibly leads him to madness. In an essay entitled "Arte e coscienza d'oggi" (1893; Saggi 865-80), Pirandello defined modern man as "slegato ... e che farnetica" ("unbound ... and raving). This new raving Subject no longer appears as a romantic hero, but rather as an anti-hero for whom language as a social institution no longer serves as an adequate means of expression. Given this totally changed existential and social condition, the role of both art and artist in society has to change. Art no longer legitimates the order of things, and so for the artist nothing remains but unmasking the lie, expressing the disorder.

The freedom that bourgeois society reached through revolution marked the end of the joyful explosion of the carnival in the public squares and relocated it, together with all serious dogmatism, within the family group. By transferring dogmatism into the family, social liberation made that dogmatism itself far more overwhelming because of the blackmail and ambiguity hidden in the love-hate relationships people entertain with their family members. The joyful relativity Bakhtin analyzes, which is typical of the carnival and of all carnivalized literature, rapidly disappears into a now neurotic literature, giving way to what Bakhtin has defined as "Dostoevsky's restrained laughter," and what Pirandello has defined as "humor" in opposition to comedy, where "oggetto del rovesciamento parodistico è lo stesso personaggio-protagonista, delegato a mostrare 'umoristicamente' i segni della sconfitta di fronte all'assolutezza dei valori 'paterni"' (Gioanola 21). These are the characteristic traits of a rich gallery of "umoristi" which includes Dostoevsky's "underground man" or "idiot," Italo Svevo's "inept," the funny hero of Kafka's America or Thomas Mann's Felix Krull, and then Musil's "man without qualities" and Pirandello's "man without identity." The typical subject of such literature is thus literally dominated by otherness, and by the irreversible division of madness, since "La folie commence là où se trouble et s'obscurcit le rapport de l'homme à la vérité" (Foucault 259). Freud has provided us with the interpretative tools required to understand nervous suffering psychologically, and therefore culturally, and has opened the way to placing neurotic-psychotic phenomena into a historical perspective-that is, to seeing them as pathological answers to the many and different pressures the environment exercises upon the Subject. ${ }^{16}$ However, comedy is the genre in which conflict with the Father becomes accepted without neurotic effects, 
and which ultimately proposes a successful opposition for the Son. This is why, according to Bakhtin, the comic mode represents the exact opposite of the tragic mode. The serio-comic and the "umoristico" modes, instead, reflect the area of neurotic opposition, of joyful and anguishing compromise, of ambivalence, and of ambiguity.

Ambivalence is a basic feature of the Pirandellian concept of subjectivity, for the Subject is constantly both "persona" and "personaggio," both creator and creature. At first the Subject performs an obsessively neurotic search for unity which finds in repetition the perfect metaphor for the Subject's basic lack of definition. In the end, however, the solution appears to lie, first of all, in the recognition of the loss of a unified identity, and secondly, in the acceptance of the fundamental disunity of an ultimately schizophrenic Subject. Therefore the integrity of the monologic-autobiographical discourse, typical of so-called "serious" genres and expressive of a fully rounded Subjectivity, soon gets replaced by the discontinuity and incongruity of the umorista's dialogic discourse. This form of discourse is typical of many of Pirandello's narrative works as well as of most of Fellini's films.

In his early novels Pirandello employs a self-assuring third-person narration, but already with Il fu Mattia Pascal, and then in such narrative works as Si gira ... and Uno, nessuno e centomila, the author as "umorista" chooses the first-person narration to exploit one of its basic features: ambiguity and ambivalence. Pirandello tries to make the most of the possibility of being both author and character, creator and created. As a result, the walls of mimetic representation are finally torn down, for what counts now is not so much what is revealed, but what is concealed. A quite similar progression can be discerned in Fellini's work, as his cinematic narratives move from the comforting objective narration of such early films as Luci del varietd (1950) and Lo sceicco bianco (1952) to the more and more subjective narration of films such as $81 / 2$. Whenever Fellini maintains that all his work is autobiographical, but then slyly adds that his autobiography has been adulterated in the process of remembering and therefore constantly reinvented, he subtly warns us against possibly expecting a comforting monologic-autobiographical discourse. What we must expect to receive from him is a multi-voiced, interior dialogue, a form of discourse particularly evident in such films as $81 / 2$ and Giulietta degli spiriti.

As Mikhail Bakhtin maintains (Problems 47-77), the introduction of the author within the hero's field of vision is one of the main features of modern narrative strategies, for it embodies the linguistic response to a new type of reflexivity which, I believe, becomes especially influential in the Postmodem period. ${ }^{17}$ Non-monologic discourse responds to new psychological conditions of man, to the knowledge modern man has of his incapacity to achieve an integral image of himself. Interior dialogic discourse offers the linguistic answer to a psychological condition characterized by the division and fragmentation contemporary man experiences. 
Anyone seeking a satisfying definition of the identity of the typical Pirandellian and Fellinian Subject ought to bear in mind that, with his essay $O n$ Humor, Pirandello moved towards acquiring an organic theory of the literary character's disintegration. Both Pirandello's dialectical theatrical scene and his evolved narrative syntax also produced an irreversible schism between the character as Raisonneur and the others. Serafino Gubbio, who in 1915 looked at the world with his insensitive eye "dall'alto" ("from above"), in 1925 turns into Vitangelo Moscarda, the hero who seizes the real "da vicino" ("from near at hand") and therefore disintegrates into innumerable epiphanies which no word can explain or author represent upon the stage. As Puppa remarks, the Pirandellian Subject clearly moves from a paranoid to a schizoid condition (Puppa 203). Such a movement from a neurotic to a psychotic state also constitutes the very foundation of the Modern Subject, and parallels the passage from comforting monologic discourse to the discontinuous, disintegrated and disintegrating dialogic discourse of the serio-comic genre, a discourse which becomes characteristic of Postmodern narrative and dramatic discourses.

The same passage may be discemed in Fellini's career. We observe characters such as Moraldo in I Vitelloni, who bears striking resemblances to Pirandello's Mattia Pascal: both are incapable of transformations or epiphanies. There are also characters such as Casanova, the archetypal neurotic Subject who reaches the point of total mechanization ${ }^{18}$ and, as such, finds a literary parallel in Serafino Gubbio, the protagonist of Pirandello's Si gira ... , since Serafino apparently reaches total mechanization, too, as he progressively becomes just a hand tuming a handle. A synchronic analysis of Fellini's entire cinematic production thus allows us to detect the same passage from a neurotic to a schizoid Subject that we find in Pirandello's artistic works. Besides characters such as Moraldo and Casanova, however, Fellini produces figures such as Guido Anselmi, the protagonist of $81 / 2$. On a psycho-linguistic level, this film can be considered a water-shed in Fellini's entire production, for Guido embodies the neurotic-schizoid passage itself. He represents a consciousness in progress, almost a meta-consciousness, while the film 8 $1 / 2$ is a work in progress, a meta-film. Metaphorically, Guido moves from the situation of Mattia Pascal to that of Serafino Gubbio, but ultimately he becomes a Vitangelo Moscarda, the man of many epiphanies, the man who avoids mechanization by disintegrating his social and his private being. He is a character who finds in the dissolution of his given social and existential image and in his "difference" the foundation for a new and fulfilling creative life.

Narrative, then, becomes the witnessing of the progressive acceptance of the schizoid condition ${ }^{19}$ by the Subject, who comes to experience the innumerable creative possibilities provided by his new, profoundly anarchist condition. Non-monologism in art thus provides the creative answer to the painful condition of the divided Self and resolves the otherwise vexing problem of the lack of a unified poetic consciousness, which in the Pirandellian 
text corresponds to the true lack of an author.

The dialogic approach towards oneself obviously breaks the ingenuous integrity of self-representation lying at the basis of lyric, epic, or tragic images of man and leads to the discovery of the Other within oneself. Therefore, according to Bakhtin, the monologue typical of "serious" genres gives way to the dialogic discourse of the carnivalized genre, which is born out of the contrast between the two Selves located within the Subject. This dialogic approach may be associated with the dualistic conception of truth which Bakhtin traces back to the Socratic dialogue. It is obviously relevant here to mention one of Pirandello's most revealing statements on this matter, as he once declared: "Umorista non è Aristofane, ma Socrate" (Umorismo 41; "Socrates is a humorist, and not Aristophanes"). ${ }^{20}$

The artistic and existential statements of both Luigi Pirandello and Federico Fellini ultimately re-state the primacy of the Subject in a social and in a literary text. This Subject-as I mentioned earlier, here defined in Lacanian terms- however, now represents the stage for an active opposition between two Selves. The only way to gain access to the "interior Self" is through the dialogic approach towards oneself, an approach which breaks the ingenuous integrity of self-representation characteristic of the comic and tragic genres. This dialogic tradition, which Bakhtin defines as "carnivalistic" and Pirandello as "umoristica," witnesses the representation of unusual and abnormal psychic states in art such as madness, split personality, unrestrained fantasizing, strange dreams, and wild passions bordering upon madness or suicide. Bakhtin maintains that Dostoevsky is responsible for the invention of all contemporary narrative structures meant to convey the totality of the neurotic-psychotic opposition. It seems a fact, then, that the modern period witnesses a clear tendency to provide narrative expression to a nervous suffering which moves from a neurotic to a schizoid stance within the Subject. Both Pirandello and Fellini obviously participate in the countertradition, which expresses in negative, or rather questioning and ambivalent terms the fundamental conflict between Father and Son, a conflict which can be detected at the very root of all the nervous sufferings troubling modern man. The linguistic answer to such a psychological condition is dialogic discourse, a discourse which aims at undermining and ultimately subverting the monologism of the Father's authoritarian discourse.

University of Toronto

\section{NOTES}

1 The affinities and obvious similarities between Pirandello's definition of "umorismo" and Bakhtin's definition of "camivalization" have been well analyzed in Elio Gioanola's introductory chapter. 
2 It would be quite interesting here to discuss Fellini's most overt statement on this matter, which is obviously the film he made on the making of the Satyricon (1969) and the "nonmaking" of Il viaggio di Mastorna, the film Fellini never made), that is Block-notes di un regista (1969). For complete references on Fellini's filmography, see Tornabene.

3 Puppa makes several poignant examples, among which the most noteworthy are the melancholic lawyer Lello Carpani in La signora Morli, una e due (1920) and even judge D'Andrea in La patente (1911). It seems relevant here though to remember the words of Zummo, the lawyer who is the protagonist of La casa del Granella (1905), "L'anima immortale, i signori spiriti che fanno? vengono a bussare alla porta del mio studio: 'Ehi signor avvocato, ci siamo anche noi, sa? Vogliamo ficcare il naso nel suo codice civile!'." (Novelle per un anno 1.312).

4 On the issue of legal discourse as the foundation for the relationship between author, character, and reader in modem narrative fiction, see Gianni Celati, 5-49.

5 For an exhaustive definition of the Pirandellian "oltre," see Debenedetti, 256-80 and 362-90.

6 Many references can be found on this and other relevant issues treated in the present essay in Fellini's precious "stream-of-consciousness" book, Fare un film.

7 It is enough to mention here Gelsomina in La strada (1954) as she can hear the "voices" of silence, or Giulietta in Giulietta degli spiriti (1965), and even the two protagonists of Fellini's most recent work, La voce della luna (1990).

8 A place in Fellini's cinematography where this important issue takes almost a didactic form is now and again Fellini: A Director Notebook.

9 Pirandello's renowned trilogy is comprised of Sei personaggi in cerca d'autore (1921), Ciascuno a suo modo (1924) and Questa sera si recita a soggetto (1930).

$10 \mathrm{I}$ am referring here to the Subject as defined by Jacques Lacan in his writings. For a definition of Subjectivity in Lacan's terms and for an understanding of the psychoanalytic premises of the present paper, see in particular the essays "The mirror stage as formative of the function of the I" (1-7), "The function and field of speech and language in psychoanalysis" (30-113), "The agency of the letter in the unconscious or reason since Freud" (146-78), and "On the question preliminary to any possible treatment of psychosis" (179-225).

11 On the problematic questions posed by any translation, see Pirandello's enlightening essay "Illustratori, attori e traduttori" (1908; Saggi, 207-24). Moreover, on Pirandello's position on the ambivalent role of the author in the birth of the character, nothing is more revealing than his above mentioned theatrical trilogy.

12 The legal situation mentioned here recalls the fantastic meeting between author and characters in both artists' work. As I discuss further in a forthcoming publication, before becoming the subject-matter of Pirandello's "theatre in the theatre" trilogy, the encounter found a first and preparatory treatment in several short stories centered on the nature of character: La tragedia di un personaggio (1911), Colloqui coi personaggi (1915), and I pensionati della memoria (1914). An understanding of the psychoanalytic and linguistic foundations of such a fantastic encounter may prove extremely insightful in our parallel analysis of Pirandello's and Fellini's artistic vision.

13 As Pirandello himself states in the Preface to the final edition of his theatre, these three works can be considered as a trilogy of the theatre in theatre since they investigate the complex problems raised both by the conflicts between text and performance, and by those born within the theatrical performance itself.

14 On the figure of the clown, as metaphor for both character and author/artist and their discourses, see Jean Starobinski, Richard Pearce, and also Gianni Celati's essay "Dai giganti buffoni alla coscienza infelice" in Finzioni occidentali.

15 On this matter, see Gioanola 7-37, Lacan 40-113 and 292-325, and Jameson, "Il postmoderno."

16 It may be relevant here to remember and reconsider Jacques Lacan's "return to Freud." For a discussion of this extremely important segment of Lacan's work, see Felman. Another study 
is particularly relevant here, in its discussion of schizophrenic behaviours as psychological answers but also as direct products of capitalistic society, that is, Gilles Deleuze and Felix Guattari's volume.

17 For a discussion of Postmodern narrative discourse, with particular reference to Pirandello's narrative works, see Gieri, but also Stone and Krysinski. Notwithstanding the extensive bibliography on Postmodernism, it seems important here to acknowledge at least three landmark studies which provide us with different yet complementary theoretical perspectives of both Postmodernism as an aesthetic movement, and Post-modernity as an historical category; such works are those by Ihab Hassan, Fredric Jameson (Postmodernism), and Jean-François Lyotard.

18 In this respect, see in particular Aldo Tassone's interview with Fellini and Dale Bradley's article but see also Joseph Markulin's quite interesting essay on character in Casanova.

19 As for a comprehensive study and a full definition of the difference between "schizoid" and "schizophrenic," see Laing. See also Deleuze and Guattari.

20 The translation is mine.

\section{WORK CITED}

Affron, Charles, ed. 8 1/2: Federico Fellini, Director. New Brunswick: Rutgers UP, 1987.

Bakhtin, Mikhail. Problems in Dostoevsky's Poetics. Ed. \& trans. Caryl Emerson. Minneapolis: U of Minnesota P, 1984.

1968.

Bradley, Dale. "History to Hysteria: Fellini's Casanova meets Baudrillard." The Hysterical Male Canadian Journal of Political and Social Theory 13.1-2 (1989): 129-39.

Celati, Gianni. Finzioni occidentali. Fabulazione, comicitd e scrittura. 1975. Torino: Einaudi, 1986.

Debenedetti, Giacomo. Il romanzo del Novecento. 1971. Milano: Garzanti, 1987.

Deleuze, Gilles, and Felix Guattari. Capitalisme et schizophrenie. 1972. Paris: Editions de Minuit, 1980.

Eco, Umberto. "The Frames of Comic Freedom." In Umberto Eco, V.V. Ivanov, and Monica Rector. Carnival. New York: Mouton Publishers, 1984.

Fellini, Federico. Fare un film. Torino: Einaudi, 1980.

"The Genesis of La Strada." In Peter Bondanella and Manuela Gieri, eds. La

Strada: Federico Fellini, Director. New Brunswick: Rutgers UP, 1987: 181-84. [First appeared in Fare un film 57-60.]

Felman, Shoshana. "The Originality of Jacques Lacan." Poetics Today 2.1b (Winter 1980-81): 45-57.

Foucault, Michel. Histoire de la folie d l'age classique. Paris: Gallimard, 1972.

Gieri, Manuela. "From Pascal to Moscarda: Pirandello's Narrative Within and Beyond Modernism." Forum lialicum 22.2 (1988): 176-186.

Gioanola, Elio. Pirandello la follia. Genova: Il Melangolo, 1983.

Hassan, Thab. The Dismemberment of Orpheus. Toward a Postmodern Literature. New York: Oxford UP, 1971.

Jameson, Fredric. Postmodernism, or, The Cultural Logic of Late Capitalism. Durham: Duke UP, 1991.

$12-18$.

"Il postmoderno." Ed. \& trans. Roberto Cagliero. SegnoCinema 12 (1984):

Krysinski, Wladimir. Le paradigme inquiet. Pirandello et le champ de la modernité. Montréal: Le Préambule, 1989.

Lacan, Jacques. Ecrits: A Selection. Trans. Alan Sheridan. New York: W.W. Norton \& Co., 1977. 
Laing, Ronald D. The Divided Self: An Existential Study in Sanity and Madness. London: Tavistock Publications, 1969.

Lyotard, Jean-François. The Postmodern Condition: A Report on Knowledge. Trans. Geoff Bennington and Brian Massumi. Minneapolis: U of Minnesota P, 1984.

Markulin, Joseph. "Plot and Character in Fellini's Casanova: Beyond Satyricon." Italian Quarterly 23.87 (Winter 1982): 65-74.

Pearce, Richard. Stages of the Clown. Perspectives on Modern Fiction From Dostoevsky to Beckett. Carbondale and Edwardsville: Southern Illinois UP, 1970.

Pirandello, Luigi. “Arte e coscienza d'oggi." Saggi, poesie, scritti varii. 865-80. On Humor. Trans. A. Illiano and D.P. Testa. Chapel Hill: U of North Carolina

P, 1974.

"Illustratori e traduttori." Saggi, poesie, scritti varii. 207-24.

Novelle per un anno. 2 vols. Milano: Mondadori, 1986.

Saggi, poesie, scritti varii. Milano: Mondadori, 1960.

"L'umorismo." Saggi, poesie, scritti varii. 15-160.

Puppa, Paolo. Dalle parti di Pirandello. Roma: Bulzoni, 1987.

Starobinski, Jean. Portrait de l'artiste en saltimbanque. Genève: Editions d'Art Albert Skira, 1971.

Stone, Jennifer. Pirandello's Naked Prompt. The Structure of Repetition in Modernism. Ravenna: Longo, 1989.

Tassone, Aldo. "Casanova: An Interview with Federico Fellini." Federico Fellini: Essays in Criticism. Ed. Peter Bondanella. New York: Oxford UP, 1978. 27-35.

Tornabene, Francesco. Federico Fellini. The Fantastic Visions of a Realist. Berlin: Benedikt Taschen, 1990. 